İş ve İnsan Dergisi I The Journal of Human and Work

Y1l | Year: Ekim | October 2019

Cilt-Sayı | Volume-Issue: 6 (2)

ss I pp: 189-197

doi: 10.18394/iid.516921

e-ISSN 2148-967X

http://dergipark.gov.tr/iid/

Araştırma Makalesi

\title{
İşe Tutulma Ölçeği Çok Kısa Versiyonu (UWES-3) Geçerlilik ve Güvenilirlik Çalışması: Alternatif Bir Versiyon (UWES-6) Önerisia
}

\author{
The Validity and Reliability Study of Work Engagement Ultra Short Version (UWES-3) \\ Proposal of an Alternative Version (UWES-6)
}

\author{
Murat Güler $^{\text {b }}$, Fatih Çetin ${ }^{c}$, H. Nejat Basım ${ }^{d}$
}

MAKALE BILLGİSİ

Anahtar Kelimeler: İşe Tutulma Ölçeği, UWES9, UWES-3, UWES-6,

Geçerlilik

Tarihler:

Gelis 23 Ocak 2019

Düzeltme geliş 17 Mart 2019

Kabul 19 Mart 2019

\begin{abstract}
ÖZ
Bu araştırmada Işe Tutulma Ölçeğinin (UWES-9) üç maddeye (UWES-3) kısaltılmış versiyonunun Türk kültürel bağlamında geçerlilik ve güvenilirlik çalışması yapılmıştır. Ayrıca 9 maddelik formda orijinal çalışmada da tespit edilen yapısal problemlere yönelik olarak işe tutulma ölçeğinin altı maddelik alternatif bir versiyonu incelenmiştir. Anket yöntemiyle 434 katılımcıdan toplanan veri kullanılarak yapılan analizler sonucunda İse Tutulma Ölçeğinin üç maddeli çok kisa versiyonu yapısal olarak geçerli ve güvenilir bulunmuş ayrıca ölçeğin dokuz maddeli versiyonu ile benzer ölçüm değerleri sağladığ görülmüştür. Diğer yandan işe tutulma ölçeğinin üç alt boyutuyla birlikte ölçülmesi amaçlandı̆̆ında yapısal geçerliliğe yönelik bazı problemli maddelere sahip dokuz maddeli ölçek versiyonu yerine 3 boyutlu 6 maddeli versiyonun (UWES-6) yapısal olarak daha iyi değerler sağladı̆̆ tespit edilmiştir. Araştırma sonucunda Türkiye'de yapılacak çalışmalarda işe tutulmanın en az maddeyle tek boyutlu bir yapı olarak ölçülmesinin istenildiğ $i$ hallerde üç maddeli formun kullanılabileceği, üç alt boyutlu olarak ölçülmek istendiğinde ise altı maddelik versiyonun kullanılabileceği önerilmiştir.
\end{abstract}

A R T I C LE INF O

\section{Keywords:}

Work Engagement Scale, UWES-9, UWES-3, UWES-6,

Validation

Article history:

Received 23 January 2019

Received in revised form 17

March 2019

Accepted 19 March 2019

\begin{abstract}
A B S T R A C T
In this research, the validity and reliability study of the ultra-short three-item version (UWES-3) of Work Engagement Scale (UWES-9) was conducted for the Turkish culture and an alternative six-item version was proposed. As a result of the analysis based on the collected data from 434 participants by questionnaire method, it was seen that the three-item short version was structurally valid and reliable and also provided similar measurement values compared to the nine-item version. Also, the 6-item version (with 3 sub-dimensions) of work engagement scale (UWES-6) provided structurally better validity values than the nine-item scale when the research interest is to measure engagement with sub-dimensions. Finally, it is suggested that the 3-item ultra-short version of UWES is applicable for measuring job engagement briefly with a single factor, and the 6-item version of UWES is better for measuring job engagement regarding its sub-dimensions in the Turkish context.
\end{abstract}

\footnotetext{
${ }^{\mathrm{a}}$ Bu çalışma, yazarların 17. Uluslararası Katılımlı İşletmecilik Kongresinde (2018) sundukları bildirinin genişletilmiş halidir.

b İletişim kurulacak yazar, Dr. Öğr. Üyesi, Niğde Ömer Halisdemir Üniversitesi, İktisadi İdari Bilimler Fakültesi, Issletme Bölümü,

Niğde, Türkiye.E-mail: murat_guler@ohu.edu.tr.ORCID:0000-0001-7370-2976

c Prof. Dr., Niğde Ömer Halisdemir Üniversitesi, İktisadi İdari Bilimler Fakültesi, İşletme Bölümü, Niğde, Türkiye. E-mail: fcetin@ohu.edu.tr. ORCID: 0000-0002-2487-9553

d Prof. Dr., Başkent Üniversitesi, İktisadi İdari Bilimler Fakültesi, İsletme Bölümü, Ankara, Türkiye. E-mail: nbasim@baskent.edu.tr. ORCID: 0000-0002-3407-5049
} 


\section{GİRIŞ}

İşe tutulma teorisi çalışanların başarılı performansının kendilerini duygusal yatırım yoluyla işlerine adamalarıyla gerçekleşebileceğini öne sürmektedir (Britt, Dickinson, Greene \& Mckibben, 2007; Kahn, 1990). İşe tutulma kavramı, çalışanın fiziksel, zihinsel ve duygusal olarak kendisini iş rolüne vermesini, kendini işe koşmasını ifade etmektedir (Kahn, 1990: 694). Bireysel ve örgütsel değişkenlerin çalışanların performanslarıyla ilişkilerinin açıklanmasında işe tutulmanın, önemli bir işlevi olduğu düşünülmektedir (Rich, Lepine \& Crawford, 2010; Salanova, Agut \& Peiro, 2005; Tims ve Akkermans, 2017). Örneğin algılanan örgütsel desteğin ve çalışanların bireysel bir özelliği olan temel benlik değerlendirmelerinin, iş performansı üzerindeki etkisinde işe tutulmanın anlamlı bir aracılık rolü bulunmaktadır ve bu rol, iş tatmini, içsel motivasyon gibi değişkenlerin aracılık rolünden daha güçlü görünmektedir (Rich vd., 2010).

Kahn (1990) tarafindan öne sürülen işe tutulma kavramı hakkındaki hipotezlerin sınanabilmesi ve görgül olarak araştırılmasında Schaufeli, Salanova, Gonzalez-Roma ve Bakker (2002) tarafindan Utrecht İşe Tutulma Ölçeğinin (UWES) geliştirilmesinin önemli katkıları olmuş ve günümüze kadar ölçeğin madde sayısını azaltmaya yönelik iki önemli revizyon yapılmıştır. Schaufeli ve arkadaşları (2002) işe tutulmayı, enerjik olma, kendini işe adama ve kendini işe kaptırma alt boyutlarıyla karakterize edilen kalıcı ve olumlu duygusal-bilişsel bir durum olarak ele almışlardır. UWES'in 2002 yılında geliştirilen ilk formunda işe tutulmanın üç alt faktörü içeren bir yapıda ve 7'li Likert tipi derecelendirmeye sahip 17 madde ile ölçülebileceği belirtilmiştir (Schaufeli vd., 2002). UWES'in alt boyutlarının Kahn'ın (1990) işe tutulma kavramsallaştırmasında belirttiği fiziksel, duygusal ve bilişsel tutulma içeriğiyle birebir örtüşmediğini belirtmek gerekir. Bununla birlikte bilimsel çalışmalarda işe tutulma düzeyinin ölçülmesinde Utrecht İşe Tutulma Ölçeği'nin en yaygın kullanılan ölçüm aracı olduğu söylenebilir (Farndale vd., 2014, Schaufeli vd., 2017). Sonraki y1llarda kavramsal olarak ölçeğin söz konusu üç alt boyutunu içeren ve 9 maddeye kısaltılmış versiyonu olan UWES-9 geliştirilmiştir (Schaufeli, Bakker \& Salanova, 2006). Son olarak, teorik olarak aynı yapıyı kapsayan ve daha az maddeli ölçüm araçlarına yönelik giderek artan ilgiyi karşılamak amacıyla, katılımcıların kısa sürede doldurabilecekleri UWES ölçeğinin 3 maddeye kısaltılan çok kısa versiyonu olarak UWES-3 geliştirilmiştir. Ölçek üç alt boyutu kavramsal olarak temsil eden birer maddenin toplamından oluşmaktadır ve işe tutulmayı tek boyutta ölçmektedir (Schaufeli vd., 2017).

UWES-3 ölçeğinin geçerlilik çalışması Schaufeli ve arkadaşları (2017) tarafından beş farklı ülkeyi (Finlandiya, Japonya, Hollanda, Belçika ve İspanya) kapsayan bir araştırma kapsamında yapılmış, iç tutarlılı̆̆ doğrulanmıştır. İşe tutulmanın ölçüt bağımlı geçerliliği kapsamında, öznel iyi oluş, iş talepleri, iş kaynakları ve iş çıktılarını temsil eden değişkenlerle ilişkileri incelenmiş ve 9 maddelik versiyonla kıyaslandığında 3 maddelik versiyonun sayılan değişkenlerle korelasyon değerlerinin ortalama olarak .02 değerinde farklılaştığı ileri sürülmüştür. Söz konusu çalışma sonucunda, işe tutulmanın güvenilir ve geçerli bir biçimde ölçülmesi amacıyla UWES'in 3 maddeli versiyonunun, 9 maddeli versiyonun yerine kullanılabileceği, bununla birlikte işe tutulmayı alt boyutlarıyla araştırmak isteyenlerin ise 9 maddeli versiyonu kullanabileceği tavsiye edilmiştir (Schaufeli vd., 2017).

Örgütsel davranış araştırmaları alanında sıklıkla kullanılan öz-değerlendirmeye dayalı ölçeklerin uzun ve çok sayıda maddelere sahip olması durumu, anket formlarının katılımcilar tarafindan doldurmaya ikna edilmesi ve samimi bir biçimde doldurulmasının sağlanması güçlüklerini beraberinde getirmektedir. Ölçeklerin madde sayısının fazlalığı güvenilirlik düzeyinde artış sağlama potansiyeli barındırsa da nitelikli veri elde edilmesini, küçük örneklem düzeylerinde yapısal geçerliliğin sağlanmasını ve nicel analizlerin yapılmasını sınırlayabilmektedir. Her ne kadar madde azaltma düşüncesi, ölçeğin ölçümlediği teorik kavramı kapsayabilme düzeyini azaltabileceği veya istenen düzeyde temsil edemeyebileceğine yönelik endişeleri beraberinde getirse de ölçeklerin faktör yapılarını incelemek için madde sayılarına oranla daha düşük örneklem sayılarının yeterli olabilmesi ve ayrıca daha iyi uyum istatistikleri elde edebilme avantajları söz konusu endişeleri gidermektedir. $\mathrm{Bu}$ düşünceyle birçok ölçüm aracının istenen yapıyı ölçebilme yeterliliğini sağlayabilen kısa formlarının geliştirilmesi çalışmaları giderek önem kazanmaktadır. Ulusal düzeyde yapılan araştırmalarda da ölçme ve analiz etme aşamalarındaki güçlükleri aşabilmek için az sayıda maddeye sahip olan, geçerliği ve güvenilirliği yüksek düzeyde olan ölçeklerin kullanılmasının faydalı olabileceği düşünülmektedir. $\mathrm{Bu}$ amaçla mevcut çalışmada işe tutulmanın incelendiği araştırmalarda kullanılabilecek UWES-3 ölçeğinin ulusal bağlamda güvenilirliği ve geçerliği incelenerek yazına kazandırılması amaçlanmıştır. 
Mevcut araştırmada işe tutulma ölçeğinin farklı versiyonlarının yapısal geçerlilikleri karşılaştırılırken kullanılan ölçüm modelinde temelbenlik değerlendirmeleri ile birlikte incelenmesi uygun görülmüş ayrıca, işle ilgili bir özellik olarak işin ilgi çekiciliği ve demografik değişkenler olarak cinsiyet ve yaş değişkenleri kullanılmıştır. Temelbenlik değerlendirmesi Kahn'ın (1990) işe tutulmayı kavramsallaştırırken ileri sürdüğü psikolojik hazır oluş kavramıyla örtüşmektedir (Rich vd., 2010). Psikolojik olarak hazır olanlar kendi fiziksel, bilişsel ve duygusal enerjilerini iş rollerine daha fazla verebilirler. Psikolojik hazır oluşu etkileyen temel faktörlerin başında kişinin kendi durumuna ve yeteneklerine olan güveni gelmektedir (Kahn, 1990). Kişinin kendinin değerliliği, etkililiği ve yeteneklerine yönelik değerlendirmeleri olarak ifade edilen temel-benlik değerlendirmeleri (Judge, Locke \& Durham, 1997) büyük ölçüde Kahn'ın (1990) belirttiği kișinin kendine güvenini yansıtmaktadır (Rich vd., 2010). $\mathrm{Bu}$ nedenle araştırmada işe tutulma ölçek versiyonlarının doğrulayıcı faktör analizlerinde (DFA) ișe tutulmayla ilişkili ancak farklı bir yapı olan temel-benlik değerlendirmelerinin içerisinde bulunduğu ölçüm modelleri kullanılmıştır.

\section{YÖNTEM}

\subsection{Katılımcılar}

Araştırmanın katılımcıları farklı işlerde çalışan yaşları 21 ile 72 arasında değişen (Ort=38,89, $\mathrm{SS}=8.03), \quad 265^{\prime} \mathrm{i}$ erkek $(\% 61,1), \quad 169$ 'u kadın $(\% 38,9)$ toplam 434 kişiden oluşmaktadır. Katılımcılar, araştırmaya gönüllü katılan kolayda seçimlik bir örneklemdir.

\section{2. Ölçüm Araçları}

\subsection{1. İşe Tutulma Ölçeği}

Araştırmada işe tutulma düzeyi Schaufeli ve diğerleri (2006) tarafından geliştirilen 9 maddelik Utrecht İşe Tutulma Ölçeği Kısa versiyonu (UWES-9) kullanılarak ölçülmüştür. Ölçeğin Türkçeye uyarlaması Eryılmaz ve Doğan (2012) ile Özkalp ve Meydan (2015) tarafından yapılmıştır. Ölçeğin her biri üçer maddeden oluşan enerjik olma, kendini işe adama ve kendini işe kaptırma olmak üzere üç alt boyutu bulunmaktadır. Ölçeğin ilk orijinal formu Schaufeli ve arkadaşları (2002) tarafindan 17 madde olarak geliştirilmiş ve daha sonra 9 maddeye kısaltılmıştır (Schaufeli vd., 2006). Utrecht İşe Tutulma Ölçeğinin ikinci kez kısaltılan versiyonu olan UWES-3 ölçeği UWES-9 ölçeğinin 1'inci, 3'üncü ve 9'uncu maddelerinden oluşmaktadır. 6'lı Likert tipi derecelendirmeye sahip ölçek maddeleri ekte sunulmuştur. 9 maddelik formun tek boyutlu yapısına yönelik olarak on farklı ülkede yapılan geçerlilik çalışmalarında Cronbach Alfa iç tutarlılık katsayısı .85 ile .92 arasında bulunmuştur (Schaufeli vd., 2006). Mevcut araştırmada UWES-9 ölçeğinin Cronbach Alfa güvenilirlik katsayısı .94 olarak iyi seviyede bulunmuştur.

\subsubsection{Temel Benlik Değerlendirmeleri}

Katılımcıların temel benlik değerlendirmelerini ölçmek üzere Judge ve arkadaşları (2003) tarafindan geliştirilen ve Şeşen (2010) tarafından Türkçeye uyarlanan 12 maddelik Temel-Benlik Değerlendirmeleri Ölçeği kullanılmıştır. Ölçek, bireylerin öz yeterliliğini, öz saygısını, nevrotikliğini ve dış kontrol odağını birleşik bir yapıda temel-benlik değerlendirmesi olarak ölçmektedir. Türkçe uyarlama çalışmasında, 5'li Likert tipi derecelendirmeye sahip olan ölçeğin tek boyutlu yapısının Cronbach Alfa güvenilirlik değeri .85 olarak raporlanmıştır (Şeşen, 2010). Mevcut çalışmada olumlu (öz yeterlilik ve öz saygı) ve olumsuz benlik (nevrotiklik ve diş kontrol odağı) olarak iki boyutlu olarak doğrulanan ölçek yapısında, Cronbach Alfa güvenilirlik değeri olumlu benlik boyutu için .78, olumsuz benlik için .71 olarak bulunmuştur.

\subsection{3. İşin İlgi Çekiciliği}

Katılımcıların yaptıkları işlerini ne kadar ilgi çekici bulduklarını ölçmek için Hackman ve Oldham'ın (1975) İş Özellikleri Anketi'nden Basım ve Şeşen (2009) tarafindan Türkçeye uyarlanan iş tatmini ölçeğinden 5'li Likert tipi cevaplama seçeneği bulunan "Mevcut işimin, bulabileceğim diğer işlerden daha ilgi çekici olduğunu düşünüyorum" maddesi kullanılmıștır.

\section{BULGULAR}

\subsection{Yapısal Geçerlilik}

İşe tutulma ölçeğinin farklı versiyonlarındaki beş farklı yap1, cinsiyet, yaş, temel-benlik değerlendirmeleri ve işin ilgi çekiciliği değişkenleriyle ilişkilerinin incelendiği 7 ayrı modelle doğrulayıcı faktör analizi (DFA) yapılmış ve modellerden elde edilen uyum iyilik değerleri birbiriyle karşılaştırılmıştır. Elde edilen sonuçlar Tablo 1'de sunulmuştur. Analizler IBM AMOS 23 programı kullanılarak yapılmıştır.

Birinci modelde işe tutulma ölçeğinin 9 maddeli ve tek boyutlu temel versiyonu test edilmiştir. Bu modelle yapilan DFA analizinde Tablo 1'de 
Tablo 1: Doğrulayıcı Faktör Analizleri Uyum İyilik Değerleri

\begin{tabular}{llllllll}
\hline Model & $\mathbf{X}^{\mathbf{2}}$ & $\mathbf{s d}$ & $\mathbf{X}^{2} / \mathbf{s d}$ & NFI & TLI & CFI & RMSEA \\
\hline UWES-9 & & & & & & & \\
\hline $\begin{array}{l}\text { 1. Tek Boyut/9 Madde } \\
\text { 2. Tek Boyut/9 Madde }\end{array}$ & 1103.382 & 240 & 4,597 & .806 & .816 & .840 & .091 \\
$\begin{array}{l}\text { (iyileştirilmiş) } \\
\text { 3. 3 Boyut/9 Madde }\end{array}$ & 554.162 & 238 & 2.328 & .902 & .932 & .941 & .055 \\
\hline & 664.847 & 237 & 2.805 & .883 & .908 & .921 & .065 \\
UWES-6 (Tr) & & & & & & & \\
4. 3 Boyut/6 madde & 356.596 & 174 & 2.049 & .921 & .949 & .957 & .049 \\
5. Tek Boyut/6 madde & 912.062 & 177 & 5.153 & .798 & .797 & .829 & .098 \\
$\begin{array}{l}\text { 6. Tek Boyut/6 madde } \\
\text { (iyileştirilmiş) }\end{array}$ & 362.276 & 175 & 2.070 & .920 & .948 & .956 & .050 \\
\hline
\end{tabular}

\section{UWES-3}

$\begin{array}{llllllll}\text { 7. Tek Boyut/3 madde } & 295.775 & 123 & 2.405 & .877 & .905 & .923 & .057\end{array}$

$\chi 2 /$ sd $=$ ki kare serbestlik derecesi oranı, NFI = Normlaştırılmış uyum indeksi, TLI= Tucker Lewis indeksi, $\mathrm{CFI}=$ Doğrulayıcı uyum indeksi, RMSEA $=$ Yaklaşık hataların ortalama karekökü

görüldüğü üzere kabul edilebilir uyum iyilik değeri elde edilememiștir $\left(\mathrm{X}^{2} / \mathrm{sd}=4.60, \mathrm{NFI}=.81, \mathrm{TLI}=\right.$ $.82, \mathrm{CFI}=.84, \quad \mathrm{RMSEA}=.09)$. Modifikasyon değerleri 1şı̆̆ında ișe tutulma ölçeğindeki iki çift maddenin (\#1 ve \#2,\#8 ve \#9) hatalarının Şekil 1'de görüldüğü gibi ilişkilendirildiği iyileştirme sonucunda ikinci modelde kabul edilebilir uyum iyilik değerleri (Byrne, 2009; Hu \& Bentler, 1999) elde edilebilmiştir $\left(\mathrm{X}^{2} / \mathrm{sd}=2.33, \mathrm{NFI}=.90, \mathrm{TLI}=.93\right.$, $\mathrm{CFI}=.94, \mathrm{RMSEA}=.06)$. Schaufeli ve arkadaşları (2017:4) tarafından da orijinal çalışmada yeterli uyum indeks değerlerine ulaşabilmek için aynı madde çiftlerinin hatalarının ilişkilendirilmesinin yapıldığ 1 bildirilmektedir (2017: 4). Ölçeğin 9 maddelik tek boyutlu yapısının kullanıldığı kültürlerarası çalışmalarda aynı problemin ortaya çıkması, ölçeğin yapısal olarak problemli maddeler içerdiğine işaret etmektedir.

Üçüncü modelde 9 maddeli işe tutulma ölçeğinin üç boyutu temsil eden maddeleri alt boyutlarına ayrılarak üç boyuttan oluşan ve ikinci seviyede tek faktörde toplanan formu test edilmiştir. Şekil 2'de görülen model üzerinde herhangi bir iyileştirme yapılmadan NFI değeri hariç (.88) büyük oranda kabul edilebilir uyum iyilik değerleri elde edilmiștir $\left(\mathrm{X}^{2} / \mathrm{sd}=2.81, \mathrm{NFI}=.88, \quad \mathrm{TLI}=.91, \mathrm{CFI}=.92\right.$, $\mathrm{RMSEA}=.07)$

Üç boyutlu 9 maddelik ișe tutulma ölçeği modelinin tüm uyum iyilik değerlerini kabul edilebilir düzeye çıkarmak için 3 maddenin $(5,6$ ve 7$)$ diğer boyutlardaki maddelerle ilişkilendirilmesi ihtiyacı olduğu görülmüştür. Ancak üç boyutlu ve 9 maddeli yap1 içerinde 3 maddenin $(5,6$ ve 7$)$ farklı alt boyutlarla ilişkilendirmesiyle yapılacak bir iyileştirme teorik olarak uygun olmadığından, modeli iyileştirmek için bu maddelerin ölçekten çıkarılması daha uygun bulunmuştur. Dikkat edildiğinde 5 ve 6 'nc1 maddeler, tek boyutlu yapıda birbiriyle ilişkilendirilen maddelerin dișında kalan, yani ölçülen yapıda diğer maddelerle birlikte bir alt boyut oluşturmasında problem olan maddelerdir. Söz konusu üç maddenin ölçekten çıkarılması neticesinde, nihai olarak elde edilen 6 maddeli 3 boyutlu alternatif bir ölçek versiyonu kullanılarak, Şekil 3'te görülen dördüncü model için DFA yapılmıştır. Elde edilen uyum iyilik değerleri iyi uyum düzeyinde bulunmuş $(\mathrm{X} 2 / \mathrm{sd}=2.05, \mathrm{NFI}=.92$, $\mathrm{TLI}=.95, \mathrm{CFI}=.96, \mathrm{RMSEA}=.05)$ ve bu modelin veriyle diğer modellerden daha iyi uyum sağladı̆̆ görülmüştür. Elde edilen üç gizil faktörlü bu yapı, her bir faktörde en az iki ilişkisiz gözlemli ölçümü içermesiyle Bollen'ın (1989) doğrulayıcı faktör analizlerinin tanımlılığ (identification) açısından öne sürdüğü "ilişkili en az iki faktör ve her faktörde ilişkisiz az iki gözlemin olması gerektiği” görüşünü desteklemektedir.

Beşinci modelde ise işe tutulma ölçeğinin 6 maddeli ve tek boyutlu versiyonu test edilmiştir (Şekil 4). Ancak, ölçüm modelinden elde edilen uyum iyilik değerleri kabul edilebilir sınırın altında kalmıştır $(\mathrm{X} 2 / \mathrm{sd}=5.15, \mathrm{NFI}=.80, \mathrm{TLI}=.80, \mathrm{CFI}=.83$, RMSEA = .10). UWES-9'da da karşılaşılan aynı iki madde çiftinin (\#1 ve \#2, \#8 ve \#9) hatalarının ilişkilendirildiği iyileştirme sonrasında altınc1 model için iyi düzeyde uyum iyilik değerleri $(\mathrm{X} 2 / \mathrm{sd}=2.07, \mathrm{NFI}=.92, \mathrm{TLI}=.95, \mathrm{CFI}=.96$, RMSEA $=.05$ ) elde edilmiştir.

Son olarak, mevcut araştırmaya konu olan Schaufeli ve arkadaşları (2017) tarafindan önerilen işe tutulma ölçeğinin üç maddelik ve tek boyutlu (UWES-3) versiyonun bulunduğu yedinci model 

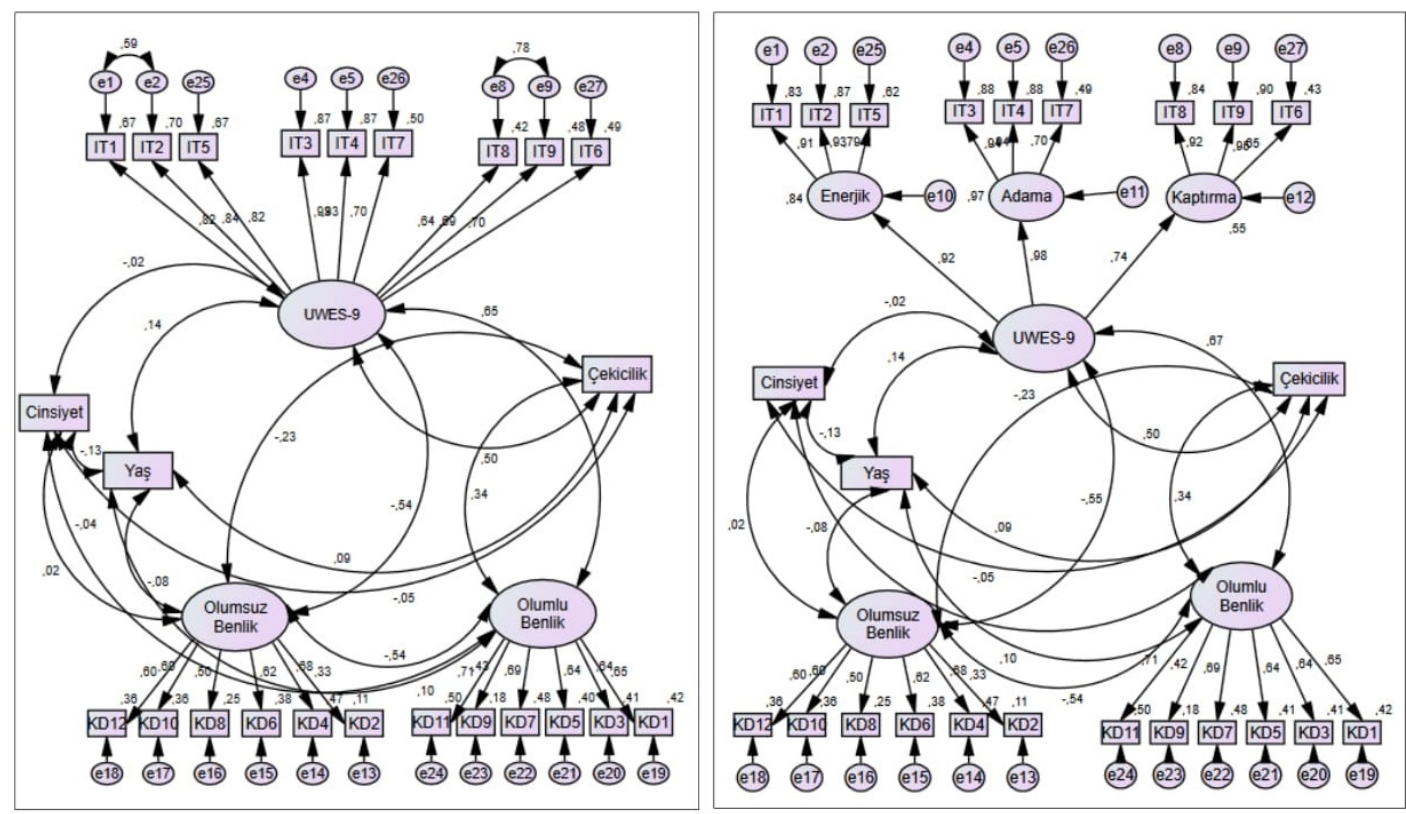

Şekil 1: Dokuz Maddeli Tek Faktörlü Model Şekil 2: Dokuz Maddeli Üç Faktörlü Model

için DFA yapılmıştır. Bu model üzerinde ölçek maddeleri arasında herhangi bir iyileştirme yapılmadan NFI değeri hariç olmak üzere kabul edilebilir uyum iyilik değerleri $\mathrm{X} 2 / \mathrm{sd}=2.41$, NFI= $.88, \mathrm{TLI}=.91, \mathrm{CFI}=.92, \mathrm{RMSEA}=.06)$ elde edilmiştir.

\section{2. İç Tutarlılık}

İşe tutulma ölçeğinin farklı versiyonlarının iç tutarlılığını incelemek amacıyla ilk olarak madde toplam korelasyonlarına bakılmıştır. Ölçeğin 9 maddeli tek boyutlu versiyonu için düzetilmiş madde toplam korelasyonları $\mathrm{r}=.68$ ile .87 arasında ve Cronbach Alfa değeri .94 olarak bulunmuştur. 9 maddeli üç boyutlu versiyonda enerjik olma boyutu için madde toplam korelasyonları $\mathrm{r}=.73$ ile .86 arasında, Cronbach Alfa değeri .90; kendini işe adama boyutu için madde toplam korelasyonları $\mathrm{r}=$ .67 ile .85 arasında, Cronbach Alfa değeri .89; kendini işe kaptırma boyutu için madde toplam korelasyonları $\mathrm{r}=.61$ ile .83 arasında, Cronbach Alfa değeri .87 olarak bulunmuştur.

Ölçeğin 6 maddeli-tek boyutlu versiyonu için madde toplam korelasyonları $\mathrm{r}=.71$ ile .85 arasında değişmektedir ve Cronbach Alfa değeri .93'tür. 6 maddeli üç boyutlu versiyonda enerjik olma boyutu için madde toplam korelasyonları her iki madde için $\mathrm{r}=.87$, Cronbach Alfa değeri .93; ișe adanma boyutu için madde toplam korelasyonları her iki madde için $\mathrm{r}=.88$, Cronbach Alfa değeri .94; kendini işe kaptırma boyutu için madde toplam korelasyonları iki madde için $\mathrm{r}=.88$, Cronbach Alfa değeri .93 olarak bulunmuştur. Ölçeğin 3 maddelik versiyonu için madde toplam korelasyonları $r=.64$ ile .78 arasında değişmektedir ve Cronbach Alfa değeri $.85^{\prime}$ tir. İşe tutulma ölçeğinin incelenen üç versiyonunun iç tutarlık düzeyleri iyi seviyede bulunmuştur.

\section{3. Ölçüt Bağımlı Geçerlilik}

İşe tutulma ölçeğinin ölçüt bağımlı geçerliliğini inceleyebilmek amaciyla farklı versiyonlarının, cinsiyet, yaş, olumlu ve olumsuz temel benlik değerlendirmesi ile işin ilgi çekiciliği değişkenleri arasındaki korelasyon değerleri hesaplanmış ve versiyonlar birbirleri ile kıyaslanmıştır. Elde edilen korelasyon değerleri Tablo-2'de sunulmuştur. İşe tutulma ölçeğinin tek boyutlu ve 9 maddelik yapısının (Şekil-1) korelasyon değerleri referans olarak ele alınmıș ve diğer versiyonların korelasyon değerleri ile aralarında görülen farklılıklar tabloda parantez içinde gösterilmiştir.

İşe tutulma ölçeğinin farklı versiyonları için elde edilen korelasyon değerleri incelendiğinde, 9 maddeli-tek boyutlu versiyon kullanılarak hesaplanan korelasyon değerlerinden en düşük düzeyde (.00 ile .01 arası) sapma 6 maddeli-üç boyutlu versiyonda gözlenmiştir. 9 maddeli ve üç boyutlu versiyon ile 3 maddeli-tek boyutlu versiyonun korelasyon değerlerindeki farklılık (.00 ile .02) arasında görülmüştür. 6 maddeli tek boyutlu versiyonun korelasyon değerlerinin farklılığ 1 ise (.00 ile .03) arasında bulunmuştur. 


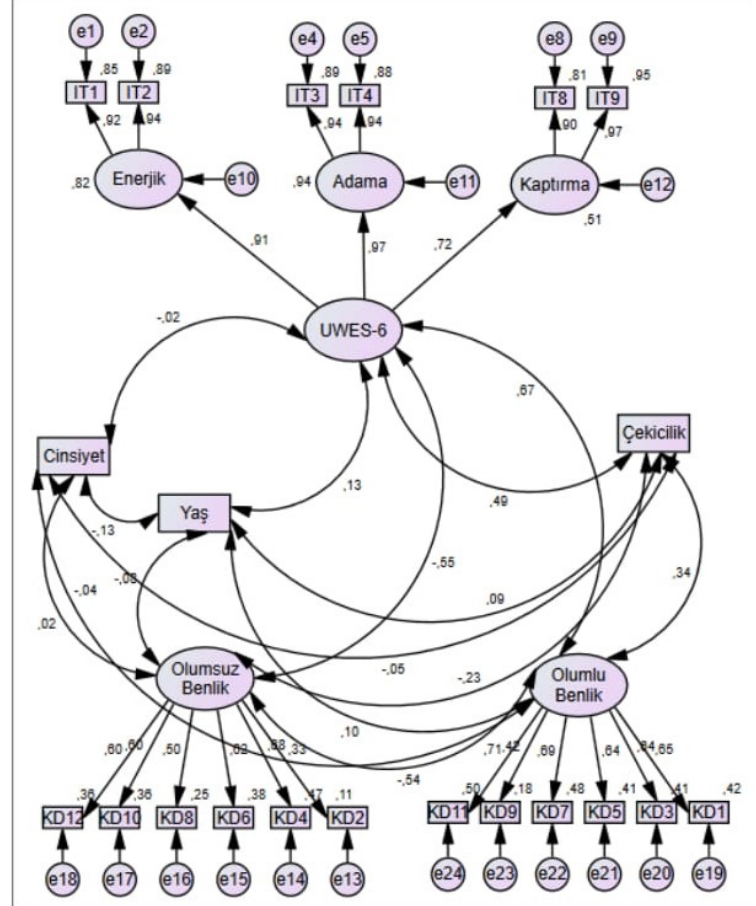

Şekil 3: Altı Maddeli Üç Faktörlü Model

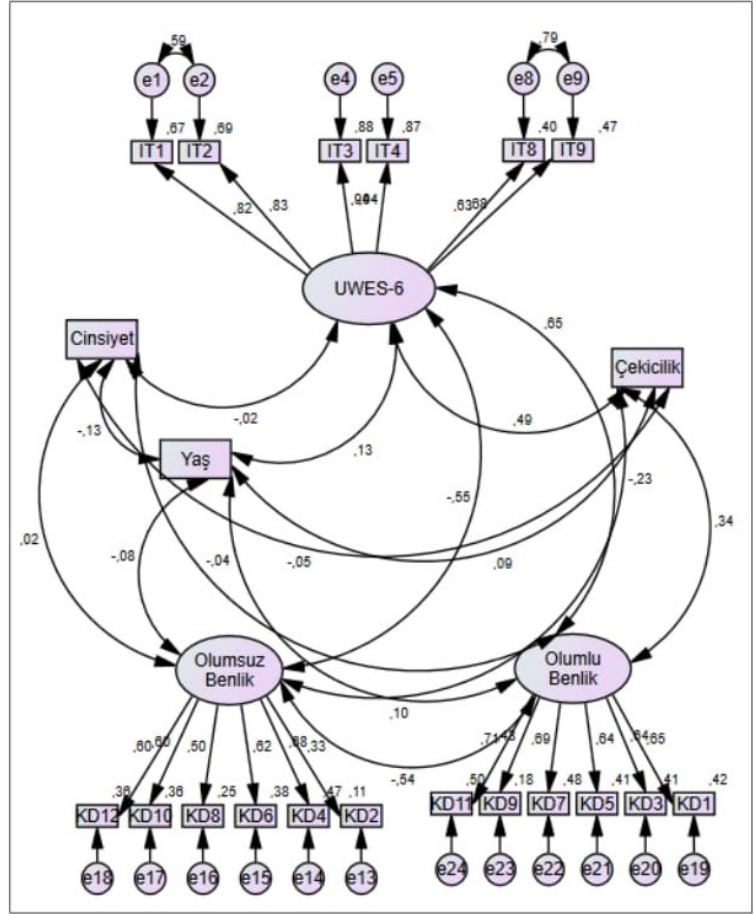

Şekil 4: Altı Maddeli Tek Faktörlü Model

Tablo 2: İşe Tutulma Ölçeğinin Farklı Versiyonlarının Korelasyon Değerleri

\begin{tabular}{|c|c|c|c|c|c|}
\hline Değişkenler & $\begin{array}{l}\text { UWES-9 } \\
\text { (1-Boyut) }\end{array}$ & $\begin{array}{l}\text { UWES-9 } \\
\text { (3-Boyut) }\end{array}$ & $\begin{array}{l}\text { UWES-6Tr } \\
\text { (1-Boyut) }\end{array}$ & $\begin{array}{l}\text { UWES-6Tr } \\
\text { (3-Boyut) }\end{array}$ & $\begin{array}{l}\text { UWES-3 } \\
\text { (1-Boyut) }\end{array}$ \\
\hline Cinsiyet & -.02 & -.02 & -.02 & -.02 & -.03 \\
\hline Yaş & $.14 * *$ & $.14 * *(.00)$ & $.13 * *(-.01)$ & $.13 * *(-.01)$ & $.14 * *(.01)$ \\
\hline Olumlu Benlik & $.65 * * *$ & $.67 * * *(.02)$ & $.66 * * *(.01)$ & $.65 * * *(.00)$ & $.67 * * *(.02)$ \\
\hline Olumsuz Benlik & $-.54 * * *$ & $-.55 * * *(.01)$ & $-.54 * * *(.00)$ & $-.55 * * *(.01)$ & $-.55 * * *(.01)$ \\
\hline İşin İlgi Çekiciliği & $.50 * * *$ & $.50 * * *(.00)$ & $.47 * * *(-.03)$ & $.49 * * *(-.01)$ & $.48 * * *(-.02)$ \\
\hline
\end{tabular}

$* \mathrm{p}<.05, * * \mathrm{p}<.01, * * *=\mathrm{p}<.001, \mathrm{n}=434$, Parantez içinde tek boyutlu 9 maddeli ölçekten farklılık belirtilmiştir.

\section{TARTIŞMA VE SONUÇ}

$\mathrm{Bu}$ çalışmada 9 maddelik Utrecht İşe Tutulma Ölçeğinin (Schaufeli vd., 2006), 3 maddeye (UWES-3) kısaltılmış versiyonunun (Schaufeli vd., 2017) Türkiye bağlamında güvenilirlik ve geçerliliği incelenmiştir. Yapılan araştırma sonucunda İşe Tutulma Ölçeğinin 3 maddelik versiyonun kabul edilebilir geçerlilik ve güvenilirlik düzeyinde olduğu ve 9 maddelik ölçek versiyonuyla benzer ölçüm değerleri sağladığı görülmüştür. Ancak, mevcut araştırmada 9 maddelik versiyonda yapısal olarak sorunlu maddelerin çıkarılmasına dayalı olarak önerilen 6 maddelik alternatif bir versiyonun yapısal olarak diğer iki versiyondan daha iyi uyum istatistikleri ve ölçüm değerleri gösterdiği bulgularına ulaşılmıştır.

Dokuz maddelik ölçek kullanılarak yapılan ölçümlerde ölçek yapısının veri ile uyumunda bazı yapısal problemler olduğu görülmüştür. Aynı problemler Finlandiya, Japonya, Hollanda, Belçika ve İspanya kültürlerinden toplanan verinin analizinde de (Schaufeli vd., 2017: 4) görülmektedir. Tek boyut altında toplanan 9 madde kuramsal olarak enerjik olma, kendini işe adama ve kendini işe kaptırma alt boyutlarını temsil etmektedir. Ancak doğrulayııı faktör analizleri iki çift maddenin alt boyutlar arasında iç içe geçmiş 
olduklarına işaret etmekte ve ölçeğin yapısal olarak uyum düzeyini düşürmektedir. Schaufeli ve arkadaşları (2017) ölçeğin 3 maddeye düşürülmüş versiyonunda bu yapısal sorunun çözülmüş olduğunu ve 9 maddeyle ölçülen yapının 3 maddeyle de ölçülebildiğini öne sürmüşlerdir. Mevcut araştırmada Schaufeli ve arkadaşları (2017) tarafından yapılan çalışmada incelenen 3 maddelik versiyonun yanında 9 maddelik ölçekte yapısal uyum sorununa neden olan her bir alt boyuttaki birer maddenin çıkarıldığı toplam 6 maddelik versiyon ve orijinal versiyon karşılaştırılmıştır. 3 maddelik tek boyutlu ölçek formu kabul edilebilir düzeyde yapısal olarak geçerli bulunmuş ve 9 maddelik ölçek formuyla benzer ölçüm değerleri sağlamıştır. Ancak mevcut araştırmada önerilen 6 maddelik işe tutulma ölçeği formu 3 alt boyuttan oluşan yapısıyla orijinal 9 maddelik formdan ve 3 maddelik formdan daha iyi uyum değerleri sağlamış ve orijinal versiyona daha yakın ölçüm değerleri üretmiştir. Bu bulgulara dayanarak, Schaufeli ve arkadaşlarının (2017) önerilerine uygun olarak, büyük bir anket formu içinde işe tutulmanın çok kısa biçimde ölçülmesinin istendiği durumda 3 maddelik tek boyutlu formun kullanılabileceği düşünülmektedir. Diğer yandan işe tutulmayı meydana getiren enerjik olma, kendini işe adama ve kendini işe kaptırma alt boyutlarıyla birlikte kapsamlı biçimde ölçülmesi istenildiğinde, Schaufeli ve arkadaşları (2017) tarafından önerilenden farklı olarak, mevcut araştırmanın yazarları tarafından 9 maddelik ölçek formu yerine üç boyutlu, (ikinci seviyede tek faktör altında toplanan) 6 maddelik ölçek formunun kullanılması önerilmektedir.

Mevcut araştırmanın en önemli sınırlılığ 1 , katılımcıların yalnızca tek bir kültürden seçilmiş olmasıdır. Ayrıca ölçeklerin geçerlilikleri için karşılaştırılan bireysel ve işle ilgili değişkenler sınırlıdır. Gelecekteki araştırmalarda, önerilen ölçek formlarının farklı kültürlerde ve farklı değişkenlerle ilişkilerinin araştırılmasıyla elde edilecek bulgularla daha genellenebilir sonuçlara ulaşılabileceği düşünülmektedir.

\section{KAYNAKÇA}

Basım, H. N. \& Şeşen, H. (2009). Örgütsel adalet algıs1örgütsel vatandaşlık davranışı ilişsisinde iş tatmininin aracılık rolü. On yedinci Yönetim ve Organizasyon Kongresi'nde sunulan bildiri, Eskişehir, 21-23 Mayıs, 2009.

Bollen, K. A. (1989). Structural equations with latent variables. New York: Wiley.

Britt, T. W., Dickinson, J. M., Greene, T. M. \& Mckibben, E. (2007). Self engagement at work. In, C. L. Cooper \& D. Nelson (Eds.), Positive organizational behavior: Accentuating the positive at work. Sage: Thousand Oaks. CA.

Byrne, B. M. (2009). Structural equation modeling with AMOS (2nd ed.). Mahwah, NJ: Erlbaum.

Eryılmaz, E. \& Doğan, T. (2012). İş yaşamında öznel iyi oluş: Utrecht İşe Bağl1lık Ölçeğinin psikometrik niteliklerinin incelenmesi, Klinik Psikiyatri, 15, 4955.

Farndale, E., Beijer, S. E., Van Veldhoven, M. J., Kelliher, C. \& Hope-Hailey, V. (2014). Work and organization engagement: Aligning research and practice, Journal of Organizational Effectiveness: People and Performance, 1, 157-176.

Hackman, R. \& Oldham, G. R. (1975). Development of the Job Diagnostic Survey, Journal of Applied Psychology, 60(2), 159-170.

Hu, L. \& Bentler, P. M. (1999). Cutoff criteria for FIT indexes in covariance structure analysis: conventional criteria versus new alternatives. $S E M, 6(1), 1-55$.

Judge, T. A., Erez, A., Bono, J. E. \& Thoresen, C. J. (2003). The core self-evaluations scale: Development of a measure, Personnel Psychology, 56, 303-331.

Judge, T. A., Locke, E. A. \& Durham, C. C. (1997). The dispositional causes of job satisfaction: A core evaluations approach. In, L. L. Cummings \& B. M. Staw (Ed.), Research in Organizational Behavior, 19, 151-188. Greenwich, CT: JAI Press.

Kahn, W. A. (1990). Psychological conditions of personal engagement and disengagement at work. Academy of Management Journal, 33, 692-724.

Meydan, C. H. \& Şeşen H. (2011). Yapısal eşitlik modellemesi AMOS uygulamaları, Ankara: Detay Yayınc1lı.

Özkalp, E. \& Meydan, B. (2015). Schaufeli ve Bakker tarafindan geliştirilmiş olan İşe Angaje Olma Ölçeğinin Türkçe'de güvenilirlik ve geçerliliğinin analizi, Isss, Güç Endüstri İlişkileri ve İnsan Kaynakları Dergisi, 17(3), 04-19. 
Rich, B. L., Lepine, J. A. \& Crawford, E. R. (2010). Job engagement: Antecedents and effects on job performance, Academy of Management Journal, 53(3), 617-635).

Salanova, M., Agut, S. \& Peiro, J. M. (2005). Linking organizational resources and work engagement to employee performance and customer loyalty: the mediation of service climate. Journal of Applied Psychology, 90, 1217-1227.

Schaufeli, W. B., Bakker, A. B. \& Salanova, M. (2006). The measurement of work engagement with a short questionnaire a cross-national study. Educational and Psychological Measurement, 66(4), 701-716.

Schaufeli, W. B., Salanova, M., Gonzalez-Romá, V. \& Bakker, A. B. (2002). The measurement of engagement and burnout: A confirmative analytic approach. Journal of Happiness Studies, 3, 71-92.

Schaufeli, W. B., Shimazu, A., Hakanen, J., Salanova, M. \& De Witte, H. (2017). An Ultra-Short Measure for Work Engagement: The UWES-3 validation across five countries. European Journal of Psychological Assessment. (Advance online publication).

Şeşen, H. (2010). Öncülleri ve sonuçları ile örgüt içi girişimcilik: Türk Savunma Sanayinde bir araştırma. (Yayınlanmamış Doktora Tezi). Kara Harp Okulu, Savunma Bilimleri Enstitüsü, Ankara.

Tims M., Akkermans, J. (2017). Core self-evaluations and work engagement: Testing a perception, action, and development path. PLOS ONE, 12(8), 1-19. 
EK 1: Ölçek Maddeleri

\section{İsee Tutulma Ölçeği Çok Kısa Versiyonu Maddeleri (UWES-3)}

\begin{tabular}{cl}
\hline 1. & İşimde kendimi enerji dolu hissederim. \\
\hline 2. & İşime karşı istekli ve hevesliyim. \\
\hline 3. & Çalışırken kendimi işime kaptırırım. \\
\hline İşe Tutulma Ölçeği Önerilen Kısa Versiyonu Maddeleri (UWES-6) \\
\hline 1. & İşimde kendimi enerji dolu hissederim. (E1) \\
\hline 2. & İşimde kendimi güçlü ve dinç hissederim. (E2) \\
\hline 3. & İşime karşı istekli ve hevesliyim. (A1) \\
\hline 4. & İşim bana çalışma şevki verir. (A2) \\
\hline 5. & Çalışırken tamamen işime yoğunlaşır dalar giderim. (K1) \\
\hline 6. & Çalışırken kendimi işime kaptırırım.(K2) \\
\hline
\end{tabular}

$\mathrm{E}=$ Enerjik olma, $\mathrm{A}=$ Adanma, $\mathrm{K}=$ Kendini kaptırma,

Belirtilen ifadeleri iş yerinde hangi sıklıkla yaşadığınızı işaretleyiniz (1 Asla/ Yılda birkaç kez ya da daha az, 2 Nadiren/ Ayda bir veya daha az, 3 Bazen/ Ayda birkaç kez, 4. Sıkça/ Haftada bir, 5 Çok sık / Haftada birkaç kez, 6 Her zaman/ Her gün) 